\title{
Correction for false statement
}

\author{
Milton Diamond
}

\section{Dear Editor,}

A false statement has been published in your journal in an article by P. A. Lee and C. P. Houk. (2010) Article ID 563640. "The Role of Support Groups, Advocacy Groups, and Other Interested Parties in Improving the Care of Patients with Congenital Adrenal Hyperplasia: Pleas and Warnings [1]."

These authors say "Confrontational tactics used by "advocacy" groups have included pressuring the medical community to adopt narrow mandates, such as a moratorium on all reproductive system surgery (six), that cannot apply to the broad range of situations encountered in practice or the use of accusations regarding therapy received by patients in the past."

In support of their argument they cite our paper (M. Diamond \& H. K. Sigmundson, Management of intersexuality. Guidelines for dealing with persons with ambiguous genitalia. Archives of Pediatrics \& Adolescent Medicine. 1997;151(10):1046-1050 [2]. We have been wrongly quoted and cited.

Here is exactly what we say:

"Perform no major surgery for cosmetic reasons alone; only for conditions related to physical/medical health. This will entail a great deal of explanation needed for the parents who will want their children to "look normal." Explain to them that appearances during childhood, while not typical of other children, may be of less importance than functionality and post pubertal erotic sensitivity of the genitalia. Surgery can potentially impair sexual/erotic function. Therefore such surgery, which includes all clitoral surgery and any sex reassignment, should typically wait until puberty or after when the patient is able to give truly informed consent." [emphasis added].

Our emphasis was on cosmetic surgery and since our statement no evidence has shown any surgery had been of benefit. Many unneeded surgeries have been devastating.

Significantly damaging were those surgeries imposed on males that were sex reassigned for different reasons. Often these were instances where the penis was considered too small for appropriate male status; e.g., the
John/Joan case $[3,4]$ but there now have been many instances recorded where males were reassigned and raised as girls and then rebelled to live as males; particularly for cases of cloacal exstrophy [5,6]. Cases of micropenis are also currently recognized as not needing surgery or sex reassignment $[7,8]$.

Creighton (2004), for example, has found "in girls with ambiguous genitalia, vaginoplasty is commonly performed during the first year of life ... although the child is unlikely to be sexually active until after puberty. There is no good evidence it is justified. [9]" And Alizai et al. (1999) reported, "The outcome of clitoral surgery was unsatisfactory (clitoral atrophy or prominent glans) in [girls] whose genitoplasty had been performed by 3 different specialist pediatric urologists. Additional vaginal surgery was necessary for normal comfortable intercourse in [other] patients. Fibrosis and scarring were most evident in those who had undergone aggressive attempts at vaginal reconstruction in infancy [10]." Minto and others [11,12] echo similar expressions against early genital surgery. Schober has stated "A reliable, successful genitoplasty procedure that can be performed early in childhood for either feminization or masculinization has not yet been developed [13]." Legal and ethical reasons against such cosmetic surgery on infants have been presented [14] and argued against [15].

Received: 3 January 2012 Accepted: 27 January 2012

Published: 27 January 2012

\section{References}

1. Lee PA, Houk CP: The Role of Support Groups, Advocacy Groups, and Other Interested Parties in Improving the Care of Patients with Congenital Adrenal Hyperplasia: Pleas and Warnings. International Journal Paediatric Endocrinology 2010

2. Diamond M, Sigmundson HK: Management of intersexuality. Guidelines for dealing with persons with ambiguous genitalia. Archives of Pediatrics \& Adolescent Medicine 1997, 151(10):1046-1050.

3. Colapinto J: As nature made him: The boy who was raised as a girl. Harper Collings, New York; 2000.

4. Diamond M, Sigmundson HK: Sex Reassignment at Birth: Long Term Review and Clinical Implications. Archives of Pediatrics and Adolescent Medicine 1997, 151:298-304.

5. Reiner WG: Gender Identity And Sex Assignment: A Reappraisal For The 21st Century. 2002.

\section{Biomed Central}


6. Reiner WG: Cloacal Exstrophy. In Child and Adolescent Psychiatric Clinics: Sex and Gender. Edited by: Diamond M, Yates A. Elsevier, Philadelphia; 2004:

7. Reilly JM, Woodhouse CRJ: Small penis and the male sexual role. The Journal of Urology 1989, 142:569-572.

8. Wisniewski A, Migeon C: Gender identity/role differentiation in adolescents affected by syndromes of abnormal sex differentiation. Adolesc Med 2002, 13:119-28.

9. Creighton SM: Adult Outcomes of Feminizing Surgery. In Ethics and Intersex. Edited by: Sytsma SE. Springer, Dordrecht, The Netherlands; 2004:207-214.

10. Alizai NK, Thomas DF, Lilford RJ, Batchelor AG, Johnson N: Feminizing genitoplasty for congenital adrenal hyperplasia: What happens at puberty? Journal of Urology 1999, 161:1588-1591.

11. Minto $\mathrm{CL}$, Creighton S: Long term sexual function in Intersex Conditions with Ambiguous Genitalia. Journal of Pediatric and Adolescent Gynecology 2002, 14:141-142.

12. Minto CL, Liao L-M, Woodhouse CRJ, Ransley PG, Creighton SM: The effect of clitoral surgery on sexual outcome in individuals who have intersex conditions with "ambiguous genitalia" a cross-sectional study. The Lancet 2003, 361:1252-1257.

13. Schober JM: Ethics and Futuristic Scientific Developments Concerning Genitplasty. In Ethics and Intersex. Edited by: Sytsma SE. Springer, Dordrect; 2006:311-317.

14. Beh HG, Diamond M: An emerging ethical and medical dilemma: Should physicians perform sex assignment surgery on infants with ambiguous genitalia? Michigan Journal of Gender and Law 2000, 7:1-63.

15. Diamond M: Pediatric management of ambiguous and traumatized genitalia. Journal of Urology 1999, 162:1021-1028.

doi:10.1186/1687-9856-2012-1

Cite this article as: Diamond: Correction for false statement.

International Journal of Pediatric Endocrinology 2012 2012:1.

\section{Submit your next manuscript to BioMed Central} and take full advantage of:

- Convenient online submission

- Thorough peer review

- No space constraints or color figure charges

- Immediate publication on acceptance

- Inclusion in PubMed, CAS, Scopus and Google Scholar

- Research which is freely available for redistribution

Submit your manuscript at www.biomedcentral.com/submit
Ciomed Central 